(c) The Author(s) 2016. This is an Open Access article, distributed under the terms of the Creative Commons Attribution licence (http://creativecommons. org/licenses/by/4.0/), which permits unrestricted re-use, distribution, and reproduction in any medium, provided the original work is properly cited.

\title{
Changes in glaciation of the Balkhash-Alakol basin, central Asia, over recent decades
}

\author{
I. SEVERSKIY, ${ }^{1}$ E. VILESOV,${ }^{2}$ R. ARMSTRONG, ${ }^{3}$ A. KOKAREV ${ }^{1}$ L. KOGUTENKO,${ }^{4}$ \\ Z. USMANOVA, ${ }^{1,2}$ V. MOROZOVA, ${ }^{5}$ B. RAUP ${ }^{3}$ \\ ${ }^{1}$ Institute of Geography, Almaty, Kazakhstan \\ ${ }^{2}$ Kazakh National University, Almaty, Kazakhstan \\ ${ }^{3}$ National Snow and Ice Data Center, University of Colorado, Boulder, CO, USA \\ ${ }^{4}$ Nanjing University of Information Science and Technology, Nanjing, China \\ ${ }^{5}$ Kazakhstan Agency of Applied Ecology, Almaty, Kazakhstan \\ Correspondence: I. Severskiy <iseverskiy@gmail.com>
}

\begin{abstract}
We describe changes in glaciers of the Balkhash-Alakol basin, central Asia, and analyse unified glacier inventories of the Zailiyskiy-Kungei and Jungar glacier systems and the Chinese part of the Ili river basin, as well as mass-balance monitoring data from Tsentralniy Tuyuksu glacier for the period 1957-2014. In spite of significant inter-basin differences, glaciation of the three glacial systems in the Ili river basin within Kazakhstan as well as within Chinese territory is changing simultaneously and similarly. Differences in the rates of glacier degradation are small and are affected primarily by the orientation of the flanks of the mountain ridges. Since the mid-1950s, glaciation of the region has remained degraded and, on average over the period examined, glaciers shrank at a rate of about $0.8 \% \mathrm{a}^{-1}$ in area and about $1 \% \mathrm{a}^{-1}$ in ice volume. Glacial systems in large basins such as BalkhashAlakol change simultaneously, linearly and at similar rates. The average rates of glacier reduction of the Zailiyskiy-Kungei, Jungar and upper Ili glacier systems for the period 1955/56-2008 amounted to $0.76 \%, 0.75 \%$ and $0.73 \% \mathrm{a}^{-1}$ respectively.
\end{abstract}

KEYWORDS: climate change, glacier hydrology, glacier mass balance, glacier volume, mountain glaciers

\section{INTRODUCTION}

Glaciers in central Asia have shrunk significantly over the past half-century and are forecasted to continue to do so. This observation has led scientists to give increased attention to climate-led changes in the mountain cryosphere (Shangguan and others, 2006; Farinotti and others, 2015; Pieczonka and Bolch, 2015). According to forecasts, glacier extent in the main river basins of central Asia during the current century could be reduced by several times or could shrink to zero if conditions remain similar to those of today (Vilesov and Uvarov, 2001; Cherkasov, 2002; Severskiy and others, 2012a).

The results of research published in the last 20 years leave no doubt that there is a reduction of glacier area in all the countries of High Mountain Asia, from the Himalaya, Hindu Kush, Karakoram and Pamir in the south to the AltaiSayan mountain system in the north (Shchetinnikov, 1998; Aizen and others, 2006; Liu and others, 2006; Narama and others, 2006; Shangguan and others, 2006; Bolch, 2007; Li and others, 2007; Niederer and others, 2007; Shi, 2008; Cogley, 2016). Results of recent English-language studies of climatic changes and their manifestation in the dynamics of mountain cryosphere components (seasonal snow cover and glaciers) and of river runoff are summarized in two review articles (Sorg and others, 2012; Unger-Shayesteh and others, 2013) and in Narama and others (2010). The content of more than 100 scientific publications during the last 20 years, most of which are devoted to the Tien Shan territory, is analyzed by Unger-Shayesteh and others (2013) with the main focus on climate-led changes in the main components of the hydrological cycle: seasonal snow cover, glaciers and river runoff. The results of that analysis can be summarized as follows.

From the 1950s to the early 1970s, glaciers in the Tien Shan remained mostly stable, though even during that period they were losing mass. An abrupt acceleration of the degradation in glaciers in all regions of the Tien Shan has been evident since the beginning of the 1970s (Cao, 1998; Vilesov and Uvarov, 2001; Liu and others, 2006; Aizen and others, 2007; Bolch, 2007; Bolch and Marchenko, 2009; Kotlyakov and Severskiy, 2009; Yao and others, 2009; Narama and others, 2010). Repeated glacier inventories are the most reliable basis for comparative evaluation of glacier response to climate change. Such catalogues exist for certain relatively small regions or basins (e.g. the Ak-Shiyrak Massif (Aizen and others, 1997); three regions differing in climatic conditions in the Tien Shan: Ili-Kungei (ZailiyskiyKungei), Pskem and the southeastern Fergana (Narama and others, 2010); and certain basins in the Gissar-Alai (Batyrov and Yakovlev, 2004) and Pamir (Desinov and Konovalov, 2007)). The results of larger-scale studies have been published recently for the central Tien Shan (Osmonov and others, 2013; Pieczonka and Bolch, 2015), the entire Tien Shan (Farinotti and others, 2015) and High Mountain Asia as a whole (Cogley, 2016). At present, evaluation of glacier changes across different mountain systems of the world is possible mainly through the regular observations of the sparse World Glacier Monitoring Service (WGMS) network for monitoring glacier mass balance (Dyurgerov and Meier, 2005; WGMS, 2008, 2013). 
The glaciation of the Balkhash-Alakol basin is one of the most studied in central Asia. For this basin, there are several comparable glacier inventories for the period 1955$2011 / 12$. These inventory data serve as the basis for the summary given below.

Glaciologists have studied the glaciation of the Balkhash-Alakol basin for many decades. The northern slope of the Zailiyskiy Alatau is the most thoroughly studied subregion (e.g. Makarevich and others, 1969, 1984; Vilesov and Uvarov, 2001; Severskiy and others, 2006, 2012b). Systematic glaciological studies, starting with the creation of the Geography Sector of the Academy of Sciences of Kazakhstan in 1938, became significantly more active under the programs of the International Geophysical Year and International Hydrological Decade, and have successfully continued within the priorities of the long-term UNESCO International Hydrological Program. Since 1957, mass-balance measurements have been conducted on central Tuyuksu glacier as part of a regular field study programme. Since 1972 these studies have been conducted year-round. The state of glaciers in this area of the northern Tien Shan is documented in the unified (similar by content) glacier inventories on the basis of aerial photography and satellite images for the years 1955, 1975, 1979, 1990 and 2008.

The glaciers of the part of the Jungar Alatau within Kazakhstan are well studied and mainly documented by Cherkasov (1969, 1970, 1975, 1980, 2002) and in recent reviews (Vilesov and others, 2013; Kaldybayev and others, 2016). For this region, unified glacier inventories have been prepared for 1956, 1972, 1990, 2000 and 2011. The glaciers of the Chilik river basin are also well studied (Vilesov, 1968; Vilesov and Uvarov, 2001), as are the glaciers of the ChonKemin and Chon-Aksu basins (Fateev and Cheban, 1969).

It is more difficult to evaluate changes in the glaciation of the Chinese part of the Ili river basin. Only two glacier inventories for this territory are known: one created on the basis of aerial photography from 1962/63 (Ding and others, 1986; Shi, 2008), and the second completed on Landsat Thematic Mapper (TM)/Enhanced TM Plus (ETM+) images for the period 2006-10 (Guo and others, 2015). There is also a study of changes of glaciers in the Keksu river basin during 1963-2004 (Gao and others, 2011).

First-order inter-basin and inter-regional differences in rates of deglaciation have been studied across the mountains of Eurasia (Shchetinnikov, 1998; Dyurgerov and Meier, 2005; Kotlyakov, 2006) as well as for glaciers worldwide (Dyurgerov and Meier, 2005; WGMS, 2008; Dyurgerov, 2010). The largest inter-regional differences are observed between zones of maritime and continental climate (e.g. in the glacier regime of the southern and southeastern periphery of the Himalaya, which is subject to a monsoonal climate, and the Hindu Kush-Karakoram and Tibetan Plateau, which are subject to a continental climate (Dyurgerov and Meier, 2005; WGMS, 2008; Dyurgerov, 2010)). These differences are determined by the nature of the mountainglacier basin (peripheral vs intra-mountainous areas), exposure and aspect of the mountain ridges, and basin orientation relative to the prevailing direction of atmospheric moisture transfer (Kotlyakov, 2004, 2006; Severskiy and others, 2006, 2009, 2012a).

The differences under study would be more reliably evaluated on the basis of comparative analysis of multiple unified glacier inventories. Unfortunately, such datasets are still rare (Nuimura and others, 2014; Pfeffer and others, 2014).

\section{DATA AND METHODS}

We completed series of glacier inventories for three main glacier systems: the Balkhash-Alakol basin, ZailiyskiyKungei (for 1955, 1975, 1979, 1990 and 2008); Jungar (for 1956, 1974, 1990, 2000 and 2011) located in Kazakhstan; and the upper Ili glacier system, located within the Chinese part of the Ili river basin, for 2000, 2008 (Kash river basin) and 2011 (whole glacier system) (Fig. 1). In addition, we used the data of the first glacier inventory of the upper Ili glacier system for 1963 completed by Ding and others (1986). These inventories are identical in content, and for each glacier contain information on length, area, volume, location, morphological type, exposure, absolute elevation of the lowest and highest points, and elevation of the firn line (used as a proxy for equilibrium-line altitude (ELA)).

\section{Glacier inventories before 1990}

E. Vilesov and R. Khonin prepared glacier inventories for Zailiyskiy Alatau for 1955, 1974 and 1979 on the basis of aerial photography. The 1955 glacier inventory was based on 1:100000 topographic maps, which were themselves based on aerial photography from 1955/56. Precision in determination of the glacier area was equal to $0.1 \mathrm{~km}^{2}$, and error in determination of the glacier area within the basins was 5-7\% (Vilesov and Khonin, 1967; Vilesov, 1968, 1969; Vilesov and Uvarov, 2001). The inventories of 1974 and 1979 are based on 1:25000 maps. The glacier area was determined by planimeter with a precision of $0.01 \mathrm{~km}^{2}$, and the error in determination of the area did not exceed $3 \%$ (Vilesov and Uvarov, 2001).

P. Cherkasov prepared glacier inventories for Kazakhstan's Jungar region for 1956 and 1972 from $1: 25000$ and $1: 50000$ topographic maps (Cherkasov, 1969, 1970, 1975, 1980). The topographic maps for 1956 and 1972 were based on aerial photography, and outlines of all glaciers were determined and transcribed from those maps. The outlines of glaciers were adjusted based on field measurements on the glaciers. In preparing the inventory of glaciers as of 1990 (Cherkasov, 2002), the area of glaciers was determined with the help of an overlay grid (reticulation) with square cells of $1 \mathrm{~mm}^{2}$ on maps of 1:25000 scale.

All morphometric parameters of glaciers were obtained by cartometric analysis of the above-mentioned large-scale topographic maps with the aid of aerial photographs from 1955 and 1956 in accordance with the recommendations of Vinogradov and others (1966). Since the accuracy in determining glacier area depends on its size, to calculate the root-mean-square error (RMSE) in measurement of the total glacier area of particular basins, all the glaciers were grouped into size classes, as determined by binning the number of divisions of an overlay grid (reticule) overlapping each glacier. The standard error of the area is defined as $m= \pm(0.38+0.044 \sqrt{F})$, where $F$ is the number of overlapping divisions of the overlay reticule, corresponding to each bin. The average error in the area measurement of the Koksu and Karatal river basins was $6.71 \%$ and $4.79 \%$, respectively (Cherkasov, 1980). This finding is consistent with the results of a similar evaluation based on satellite images, according to which the standard deviation of the digitization of the same glaciers on Landsat imagery by 


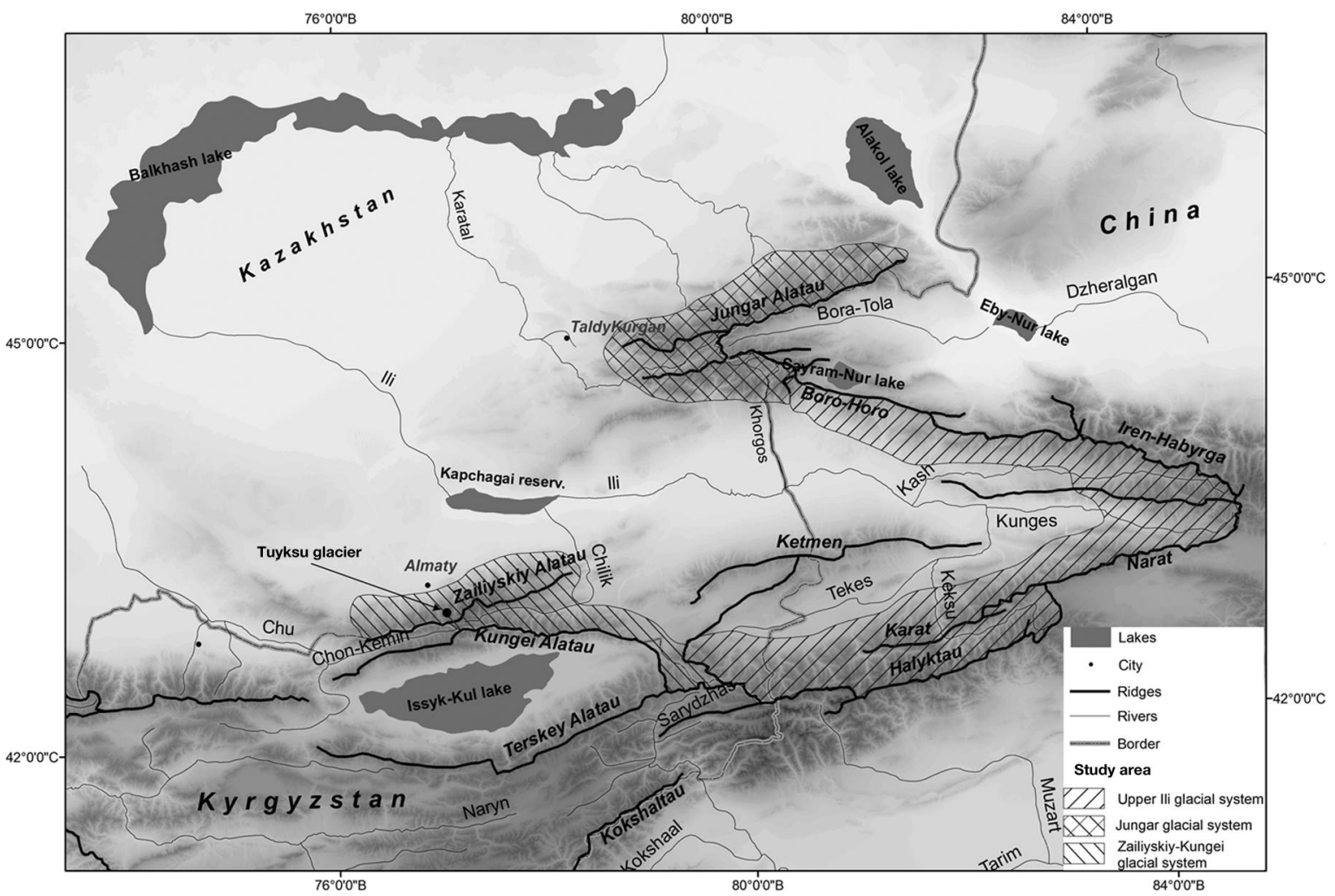

Fig. 1. Study area.

different operators varied from $2.7 \%$ to $14.6 \%$ with an average of 3.5\% (Paul and others, 2013)

\section{Glacier inventories after 1990}

Glacier inventories of the Balkhash-Alakol basin for the years following 2000, identical in content to the catalogues mentioned above, were prepared on the basis of the $1: 25000$ maps of the state survey, and on satellite images from Landsat 7 ETM+ and Landsat 8, processed to level L1T, i.e. orthorectified using a digital elevation model (DEM) and surface reference points (Table 1). The dataset GLS2000 (Global Land Survey 2000; http://landsat.usgs.gov/
GLS2000_Accuracy.php) serves as the basis for geometric correction. The RMSE in GLS2000 is less than one pixel of the image, which corresponds to an accuracy of $30 \mathrm{~m}$ or better (http://landsat.usgs.gov/GLS2000_Accuracy.php). All images were obtained from the United States Geological Survey GLOVIS (Global Visualization Viewer) website (http://glovis.usgs.gov/). The images were acquired during the ablation period with minimum seasonal snow and cloud cover. All images and maps were reprojected into a WGS84 UTM projection. The RMSE of the geometric correction was from $5 \mathrm{~m}$ to $8 \mathrm{~m}$. The error of determination of the area of select glaciers using manual digitization of glacier bound-

Table 1. Satellite imagery used in this study

\begin{tabular}{|c|c|c|c|c|}
\hline Satellite and sensor & $\begin{array}{c}\text { Resolution } \\
\text { m }\end{array}$ & Zailiyskiy Alatau & Jungar Alatau & Upper Ili river basin \\
\hline $\begin{array}{l}\text { Landsat TM, Landsat } 7 \text { ETM+, } \\
\text { Landsat } 8 \mathrm{OLI} \text { TIRS }\end{array}$ & $30 / 15$ & $\begin{array}{l}11 \text { August 2006, } \\
1 \text { September } 2008\end{array}$ & $\begin{array}{c}4 \text { September 2000, } 14 \text { September } 1999, \\
9 \text { November 2011, } 12 \text { August 2012, } \\
13 \text { August 2012, } 20 \text { August } 2012\end{array}$ & $\begin{array}{l}2 \text { August 2010, } 11 \text { September 2010, } \\
4 \text { August 2011, } 13 \text { August 2011, } \\
5 \text { September 2011, } 7 \text { September 2011, } \\
9 \text { September 2013, } 1 \text { August } 2013\end{array}$ \\
\hline IRS (LISS-3) & 23.5 & $\begin{array}{l}7 \text { September } 2006, \\
23 \text { September } 2008\end{array}$ & - & - \\
\hline ASTER & 15 & - & - & $\begin{array}{c}25 \text { August 2004, } 6 \text { August 2006, } \\
10 \text { September } 2007\end{array}$ \\
\hline ALOS & 10 & $\begin{array}{l}16 \text { August 2006, } \\
29 \text { August } 2008\end{array}$ & - & 1 August 2008, 23 September 2006 \\
\hline IKONOS & 1 & 30 August 2008 & - & - \\
\hline SRTM2 & 90 & + & - & - \\
\hline
\end{tabular}

Notes: OLI TIRS: Operational Land Imager Thermal Infrared Sensor; IRS: Indian Remote-sensing Satellite; LISS; :Linear Imaging Self-Scanning sensor; ASTER: Advanced Spaceborne Thermal Emission and Reflection Radiometer; ALOS: Japanese Advanced Land Observing Satellite; SRTM2: Shuttle Radar Topography Mission 2; GDEM2: Global Digital Elevation Model 2. 

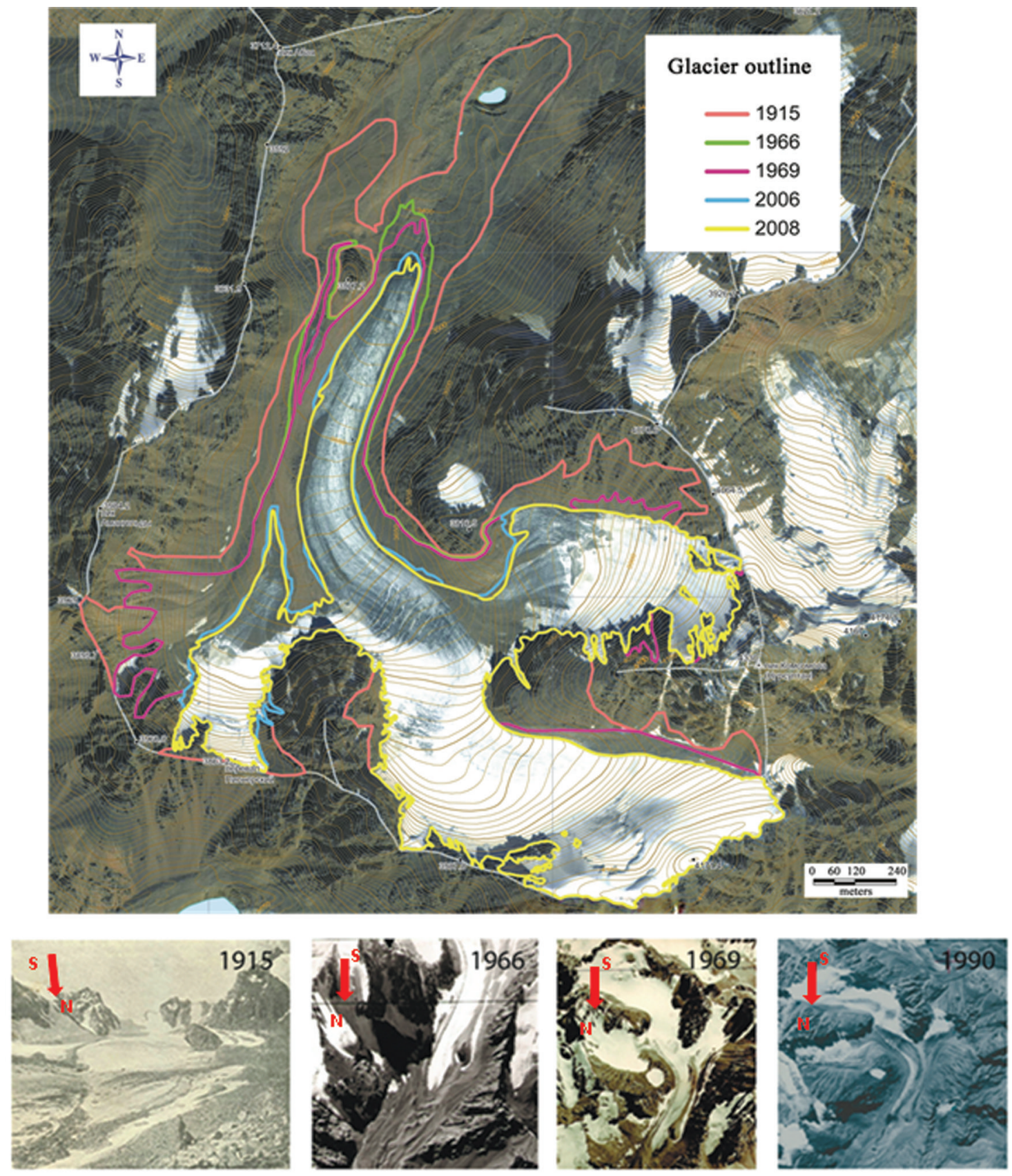

Fig. 2. Example of glacier changes: Bogdanovich glacier, Talgar river basin. Background based on IKONOS, 2008 and SRTM2. (Note: 1915 year is archive photo; 1966, 1969, 1990 years are from aerial photographs.)

aries from Landsat images is $<5 \%$, and the error of determination of the area of a larger set of glaciers $(>100)$ decreases to $<3 \%$ due to cancellation of positive and negative errors (Kutuzov, 2012; Paul and others, 2013).

Processing of the images and manual mapping of the glaciers onto them were performed according to the methods detailed in Bolch (2006), Paul and others (2009) and Kokarev and Shesterova (2011). The glacier area (debris-free ice) and surrounding moraines were mapped using false-colour composite bands (Fig. 2). Comparison of the glacier outlines from different dates allowed the determination of the reliability of the glacier boundaries. Panchromatic images with spatial resolution of $15 \mathrm{~m}$ were used along with the multispectral imagery to decrease the mapping error. Image-preprocessing steps depended on image source. Image sources include Advanced Spaceborne Thermal Emission and Reflection Radiometer (ASTER),
Indian Remote-sensing Satellite (IRS; Linear Imaging SelfScanning sensor 3 (LISS-3)), Advanced Land Observing Satellite (ALOS) and IKONOS, with resolutions of 15, 23.5, 10 and $1 \mathrm{~m}$, respectively. The DEMs SRTM2 and ASTER GDEM2 were used to aid the determination of glacier boundaries and morphometric parameters. These two DEMs helped to identify the borders between the glacier watersheds, as well as to determine more correctly the morphological type and aspect of the glaciers. Earlier assessments conducted within the GLIMS (Global Land Ice Measurements from Space) framework have confirmed that human interpretation remains the best tool for extracting detailed information from satellite imagery for many types of glaciers, particularly when mapping is conducted by the same person using a combination of different types of imagery (Kutuzov and Shahgedanova, 2009; Paul and others, 2009). 


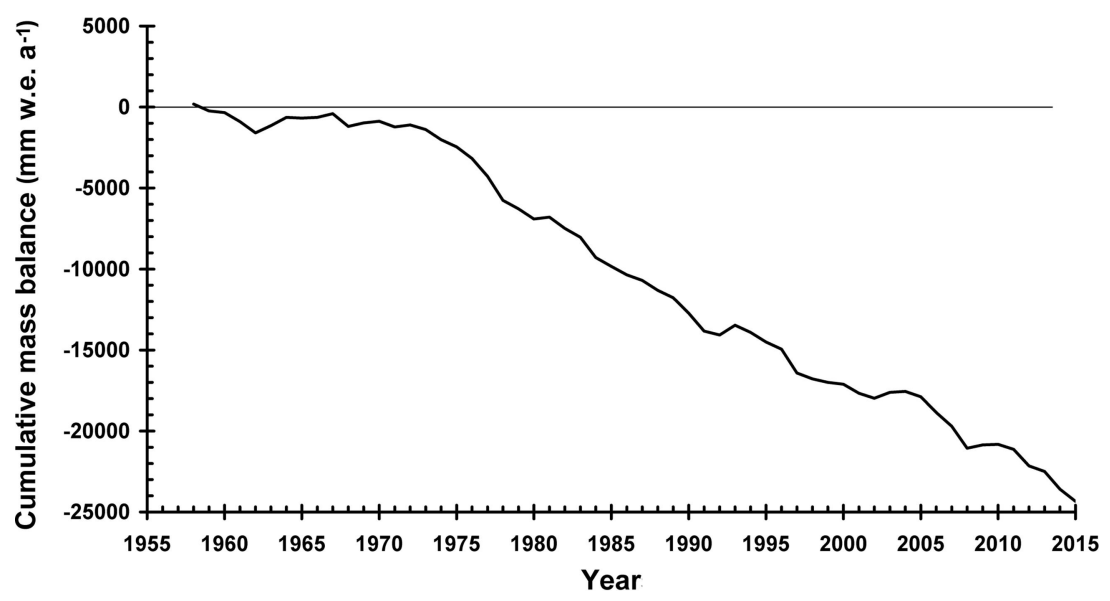

Fig. 3. Cumulative mass balance of Tuyuksu glacier for the period 1957-2015.

Changes in area of Bogdanovich glacier (Fig. 1) for the first 48 years (1915-63) are comparable to the changes over the following 45 years (1963-2008). This is consistent with changes considered below.

\section{Derivation of glacier volume}

Glacier volume was calculated based on thickness measurements of selected glaciers taken on the basis of aerial and surface radio-echo sounding (Macheret and others, 1988; Cherkasov and Nikitin, 1989). The relation between the debris-free glacier area $S\left(\mathrm{~km}^{2}\right)$ and volume $q\left(\mathrm{~km}^{3}\right)$ is approximated by a power-law function of the following type:

$$
q=a \cdot s^{b} \text {. }
$$

For larger valley glaciers with areas greater than $3 \mathrm{~km}^{2}$, this relationship is

$$
q=0.030 S^{1.379},
$$

and for cirque glaciers and valley glaciers smaller than $3 \mathrm{~km}^{2}$ it is

$$
q=0.049 S^{1.202} .
$$

The error in area as determined by Eqn (2) is $\pm 3.21 \%$, and by Eqn (3) is $\pm 8.8 \%$ (Macheret and others, 1988). We emphasize that Eqns (2) and (3) should be applied only over entire regions. These equations are based on thickness measurements of 130 selected glaciers by aerial and surface radioecho sounding in Jungar Alatau. Obviously, in other climatic conditions, the parameters in Eqns (2) and (3) may differ.

For small mountain glaciers, such as mountain apron glaciers, we propose to employ the formula used to determine the thickness of glaciers on the slopes of volcanoes of the Rocky Mountains, North America (Driedger and Kennard, 1986):

$$
q=0.022 S^{1.124}
$$

\section{RESULTS AND DISCUSSION \\ Observed changes in the mass balance of Tuyuksu glacier}

We use the glacier mass-balance time series of central Tuyuksu glacier (hereafter Tuyuksu glacier) to begin to investigate the overall character of regional glacier changes. This glacier is in the WGMS network. Since 1957, annual glaciological and hydrometeorological observations have been conducted on the glacier and, since 1972, those observations have been performed year-round, and have included measurements of all components of glacier mass balance. This continuous series of mass-balance measurements of Tuyuksu glacier exceeds 57 years.

The cumulative graph of the mass balance of Tuyuksu glacier (Fig. 3) shows the negative trend in glacier mass. The mass balance over 50 years (1958-2008) is $-18.9 \mathrm{~m}$ w.e. The water-equivalent glacier surface has lowered by $0.38 \mathrm{~m} \mathrm{a}^{-1}$ (Fig. 3). The reliability of the mass-balance data is demonstrated by the results of repeated large-scale stereophotogrammetric surveys conducted by German land surveyors in 1958 and 1998 (Gletschergebiet Tujusku, 1961; Eder and others, 2005). The comparisons of changes in the surface level of Tuyuksu glacier showed that the average mass balance for 40 years, calculated on the basis of these photogrammetric surveys, differs from the direct observations only by $0.06 \mathrm{~m}$ w.e.

The general character of changes in components of the mass balance of Tuyuksu glacier for the whole period of observations is given in Figure 4. As shown in Figures 3 and 4, between 1958 and the early 1970s the glacier remained in a relatively stable state. During this period, the annual mass balance was positive for 8 years and reached a maximum (0.50 mw.e.) in 1963 and in 1964. During the 15 years between 1958 and 1973, the values of winter balance exceeded $1.0 \mathrm{~m}$ w.e. ten times, and the annual mass balance was positive eight times. The situation changed markedly starting in 1973 and for the subsequent 5 years when the winter mass balance decreased from 0.70 to 0.30 mw.e., and summer balance increased sixfold, reaching a maximum of $1.8 \mathrm{~m}$ w.e. in 1978 . Then, after a short stable period at around $-0.60 \mathrm{~m}$ w.e., the general trend was toward negative annual mass balance, a trend which continues to the present. There was a correlation in trends of the annual and winter mass balance (Fig. 4). The abrupt change of the glacier mass balance in the early 1970s is typical for the Tien Shan as a whole (Cao, 1998). It should be noted that, in the vast majority of cases, the higher the value of the winter mass balance, the lower the loss of long-term ice in the following ablation period. The obvious reason for this is that the greater the snow accumulation during the cold period, the later the onset of ablation of multi-year ice, other factors being equal. This general pattern is violated only in years with anomalously cold summers, as is illustrated in the years 1982, 1993, 2003 and 2009 (Figs 4 and 5) in which, even 


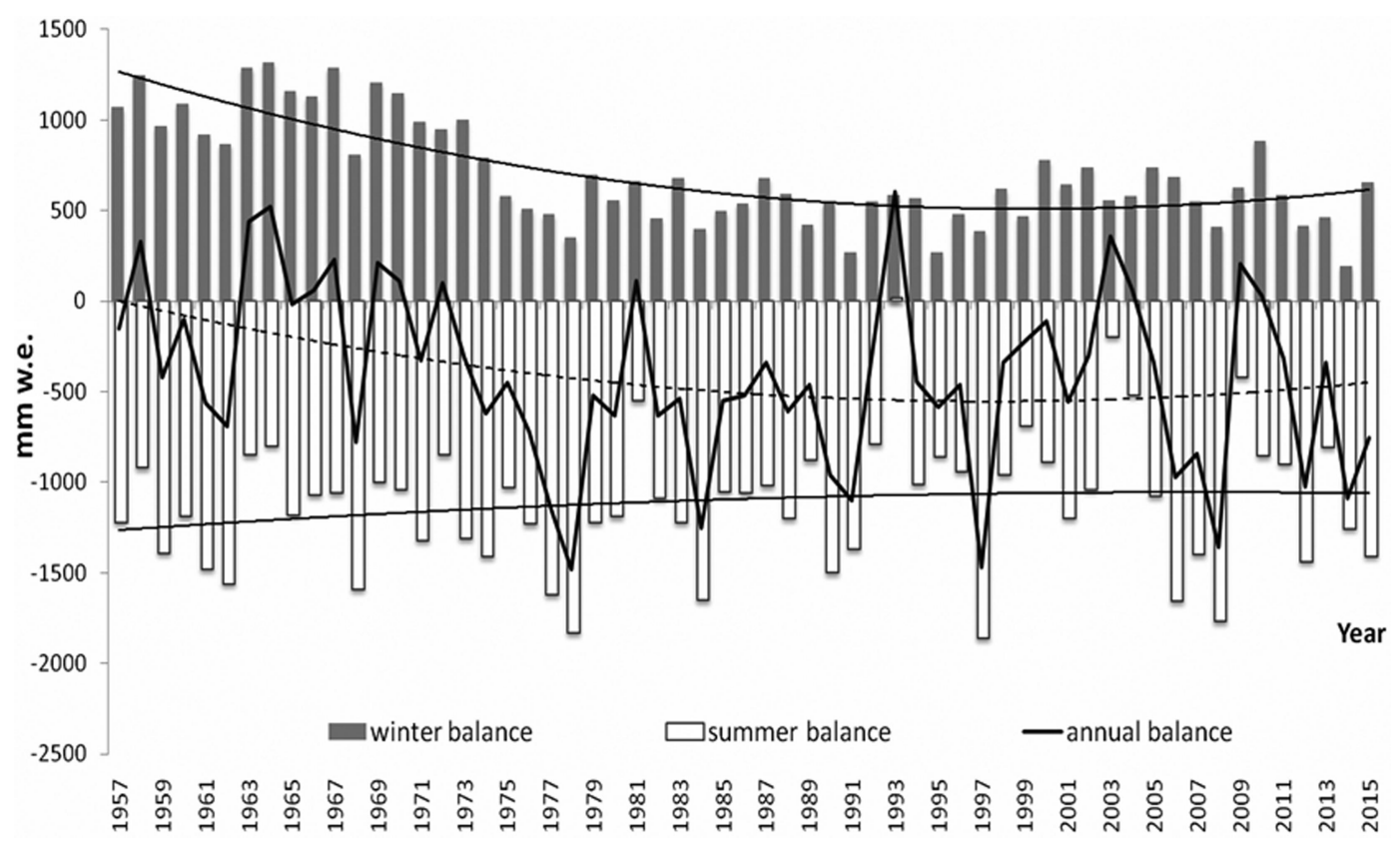

Fig. 4. Dynamics of Tuyuksu glacier mass balance for the whole period of observations.

with relatively small values of winter accumulation, the annual mass balance was close to zero or positive due to cold summers.

The observed changes in the annual balance are consistent with the observed changes through time in the glacierized area of the Zailiyskiy-Kungei glacial system. At the beginning of the study period, the rate of glacierized area reduction increased by up to $1.65 \% \mathrm{a}^{-1}$; later it decreased by $0.67 \% \mathrm{a}^{-1}$ in the first decade of the 21 st century (Severskiy and others, 2006, 2012b; Severskiy, 2009).

\section{Changes in glacierization of Zailiyskiy-Kungei glacial system}

In order to study changes in glaciation and causes of interbasin and inter-regional differences, it is important to collect data on the glacierization of the whole glacial system, i.e. sets of glaciers with common interconnections with the environment (Kotlyakov and Komarova, 2007). Studies of changes in glacial systems require synchronous cataloguing of the glaciers over significant areas for different years separated by a minimum of one to three decades. Such studies are

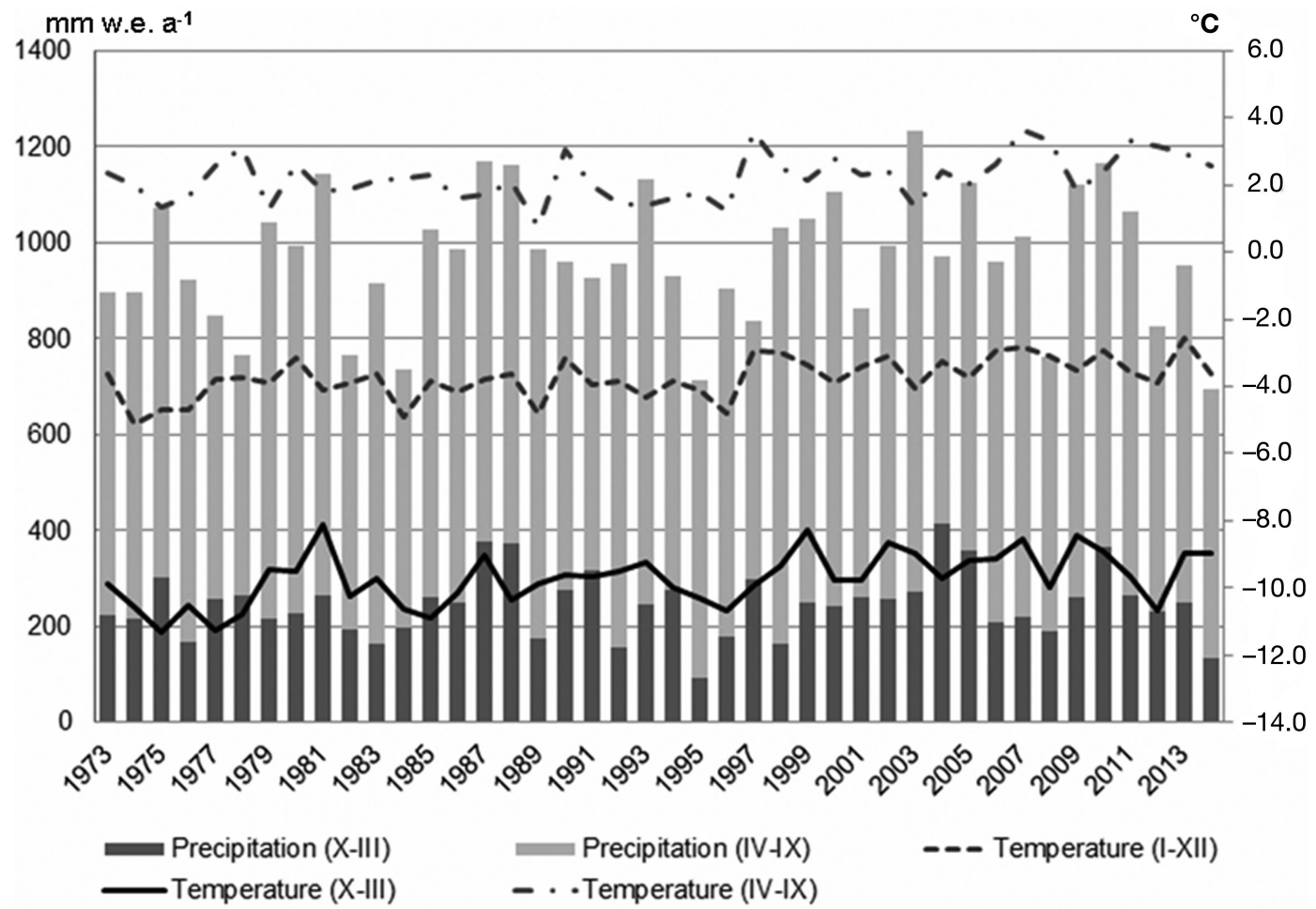

Fig. 5. Long-term average temperature and precipitation (Tuyuksu meteorological station, $3450 \mathrm{~m}$ ). 
Table 2. Changes in percentage of glacier area in particular basins relative to total glacier area on the northern slope of Zailiyskiy Alatau (only the area of debris-free ice is taken into account)

\begin{tabular}{|c|c|c|c|c|c|c|c|c|c|c|}
\hline Year & Uzun-Kargaly & Chemolgan & Kaskelen & Aksai & Kargaly & Bolshaya Almatinka & Malaya Almatinka & Talgar & Issyk & Turgen \\
\hline 1955 & 4.5 & 0.9 & 4.7 & 4.7 & 1.4 & 11.8 & 3.2 & 39.2 & 17.2 & 12.4 \\
\hline 1974 & 4.6 & 1.3 & 5.7 & 5.4 & 1.3 & 11.1 & 3.0 & 38.2 & 16.8 & 12.6 \\
\hline 1990 & 4.7 & 0.9 & 4.7 & 5.0 & 1.3 & 10.3 & 3.2 & 39.4 & 17.6 & 12.7 \\
\hline 2008 & 4.6 & 0.8 & 5.0 & 5.4 & 1.4 & 10.1 & 3.3 & 39.2 & 18.3 & 11.9 \\
\hline
\end{tabular}

relatively rare (Shangguan and others, 2009; Bolch and others, 2010).

In this context, we evaluate the utility of studying related glacial systems by monitoring particular basins. We assume that the factors that determine inter-basin and inter-regional differences in glacial systems are manifest, to some extent, in the annual glaciological characteristics and that, on average, their influence over the long term remains more or less stable.

Comparative analysis of glacier inventories that contain characteristics of the glaciers' status for the last half-century illustrates the stability of correlation between the glacierized area in a particular basin and that of the larger glacial system (Severskiy, 2011).

Table 2 shows that, for the period 1955-2008, the proportion of glacierized area of the particular river basins in the total glacierized area of the northern slope of Zailiyskiy Alatau (northern Ili glacial system) changed only slightly.

It should be pointed out that, within a single glacial system, typical rates of mass loss are high for glaciers on the southern flanks of the ridges, and relatively low for glaciers of intra-mountainous areas and orographically closed basins with an eastern aspect (Severskiy and others; 2006, 2012a,b; Severskiy, 2009).

On the basis of the results from the above-mentioned glacier inventories of the Zailiyskiy-Kungei and Jungar glacial systems, and of similar data for the Altai (Nikitin, 2009) and Gissar-Alai (Shchetinnikov, 1998), we conclude that the error in total glacierized area tends exponentially to approach a constant as that total area increases, and a threshold of $13-14 \mathrm{~km}^{2}$ can be identified above which the error changes little. The error does not exceed $\pm 10 \%$ for total glacierized areas $>5 \mathrm{~km}^{2}$, and $< \pm 5 \%$ for areas $>10 \mathrm{~km}^{2}$ (Severskiy, 2011; Severskiy and others, 2012b).

The stability of these correlations is evidence of similar responses to climate change by glaciers in particular basins to those of their corresponding whole glacial systems. This finding allows us to perform operational monitoring of the glacial systems: once the area of glaciation in the control basin and its share of total area of the glacierization in the region (or group of basins) has been evaluated, it is relatively straightforward to estimate the area of glacierization in the respective whole glacial system.

We used the data from a series of consecutive glacier inventories of the northern slope of the Zailiyskiy Alatau ridge to assess the reliability of calculating the glacierized area of a complete glacial system $S_{\mathrm{c}}$ on the basis of the glacierized area of a particular basin $S_{p}$ (Table 3). Taking the measured glacierized area of a particular basin $\left(S ; \mathrm{km}^{2}\right)$ for the current year and the share of this area in the total glacierized area of the glacial system $\left(S_{\mathrm{p}} ; \%\right)$ in the most recent previous catalogue of glaciers, it is straightforward to estimate the total value of $S_{\mathrm{c}}$ for the current year.

As follows from Table 3, for the overwhelming majority of cases $(94 \%)$, the relative error of calculation of glacierized area of the complete glacial system $S_{\mathrm{c}}$ does not exceed $10 \%$, and in $56 \%$ of cases is $<5 \%$. Judging from the data in Table 3, the glacierized area of the Aksai river basin for 1955 was substantially understated. The calculated area of the glacial system $\left(S_{\mathrm{c}}\right)$ and error of calculation $(\Delta S ; \%)$ are accordingly larger for 1974. If we accept that the share of

Table 3. Calculation of glacierized area of the northern Ili glacial system according to glacierized area of particular basin

\begin{tabular}{|c|c|c|c|c|c|c|c|c|c|c|c|}
\hline \multirow[t]{2}{*}{ River } & \multirow[t]{2}{*}{ Quantity } & \multicolumn{5}{|c|}{ Basic data for a year } & \multirow[t]{2}{*}{ Quantity } & \multicolumn{4}{|c|}{ Results of calculation } \\
\hline & & 1955 & 1974 & 1979 & 1990 & 2008 & & 1974 & 1979 & 1990 & 2008 \\
\hline \multirow[t]{3}{*}{ Aksai } & $S\left(\mathrm{~km}^{2}\right)$ & 13.5 & 13.3 & 12.5 & 10.2 & 9.3 & $S_{C}\left(\mathrm{~km}^{2}\right)$ & 283.0 & 231.5 & 188.9 & 186.0 \\
\hline & $S / S_{\mathrm{t}}(\%)$ & 4.7 & 5.4 & 5.4 & 5.0 & 5.4 & $\Delta S\left(\mathrm{~km}^{2}\right)$ & 37.9 & 2.4 & -15.8 & 14.1 \\
\hline & & & & & & & $\Delta S(\%)$ & 15.4 & 1.0 & -7.7 & 8.2 \\
\hline \multirow[t]{3}{*}{ B. Almatinka } & $S\left(\mathrm{~km}^{2}\right)$ & 33.9 & 27.2 & 25.3 & 21.0 & 17.4 & $S_{C}\left(\mathrm{~km}^{2}\right)$ & 230.5 & 227.9 & 184.2 & 168.9 \\
\hline & $S / S_{\mathrm{t}}(\%)$ & 11.8 & 11.1 & 11.4 & 10.3 & 10.1 & $\Delta S\left(\mathrm{~km}^{2}\right)$ & -14.6 & -1.2 & -20.5 & -3.0 \\
\hline & & & & & & & $\Delta S(\%)$ & -6.0 & -0.5 & -10.0 & -1.7 \\
\hline \multirow[t]{3}{*}{ Issyk } & $S\left(\mathrm{~km}^{2}\right)$ & 49.5 & 41.3 & 36.8 & 35.8 & 31.5 & $S_{C}\left(\mathrm{~km}^{2}\right)$ & 240.1 & 219.0 & 222.4 & 180.0 \\
\hline & $S / S_{\mathrm{t}}(\%)$ & 17.2 & 16.8 & 16.1 & 17.5 & 18.3 & $\Delta S\left(\mathrm{~km}^{2}\right)$ & -5.0 & -10.1 & -17.7 & 8.1 \\
\hline & & & & & & & $\Delta S(\%)$ & -2.0 & -4.4 & -8.6 & 4.7 \\
\hline \multirow[t]{3}{*}{ Turgen } & $S\left(\mathrm{~km}^{2}\right)$ & 35.7 & 31.0 & 28.9 & 26.0 & 20.5 & $S_{C}\left(\mathrm{~km}^{2}\right)$ & 250.0 & 229.4 & 206.3 & 161.4 \\
\hline & $S / S_{\mathrm{t}}(\%)$ & 12.4 & 12.6 & 12.6 & 12.7 & 11.9 & $\Delta S\left(\mathrm{~km}^{2}\right)$ & 4.9 & 0.3 & 1.6 & -10.5 \\
\hline & & & & & & & $\Delta S(\%)$ & 2.0 & 0.1 & 0.8 & -6.1 \\
\hline
\end{tabular}

Notes: $S$ : glacierized area of a particular basin; $S_{\mathrm{t}}$ : glacierized area of northern slope of Zailiyskiy Alatau ridge from glacier inventories; $S_{\mathrm{c}}$ : calculated area of glacier ice of the northern slope of Zailiyskiy Alatau ridge; $\Delta S$ : difference between the calculated $S_{\mathrm{c}}$ and the actual $S_{\mathrm{t}}$ of the glacierized area. 
glacierized area of the Aksai river basin $\left(S / S_{t} ; \%\right)$ is equal to $5.4 \%$, which is typical for 1974, 1979 and 2008, then the calculation error $(\Delta S ; \%)$ does not exceed $0.5 \%$. Thus, we can conclude that the results of the calculation of the glacierized area of a complete glacial system based on the glacierized area of the particular basin are close to actual values.

The stability of the studied correlations allows comparative analysis of the condition of the different glacial systems and investigation of the reasons for inter-basin and interregional differences in response of the glacial systems to climate changes.

The correlations between the areas of particular glaciers and of glaciers in the corresponding basin are stable in time and allow us to use the areas of particular glaciers to estimate the glacierized area in the whole basin, significantly extending opportunities for monitoring the dynamics of glacierization in different regions and for reconstructing mountain glaciation on the basis of photographs and instrumental surveys of particular glaciers made before satellite-based glacier inventories.

Table 4 and Figure 6 show the respective data of glacierization on the northern slope of the Zailiyskiy Alatau ridge and in the Chilik river basin. These results suggest that glaciation in these basins during the last half-century changed linearly (Fig. 6) at rates that differed only moderately (between -0.57 and $-0.76 \% \mathrm{a}^{-1}$ ). Glacier area in the Zailiyskiy-Kungei glacial system decreased by 35\% during the period 1955-2008. Maximum rates of shrinkage $\left(-1.65 \% a^{-1}\right.$ for glacierization of the Zailiyskiy-Kungei system on average) were observed from 1975 to 1979 . On average, during the period 1955-2008, the most intensive glacier area loss was typically for glaciers on the northern slope of Zailiyskiy Alatau, and the least intensive for the orographically closed Chilik river basin (Table 4 ).

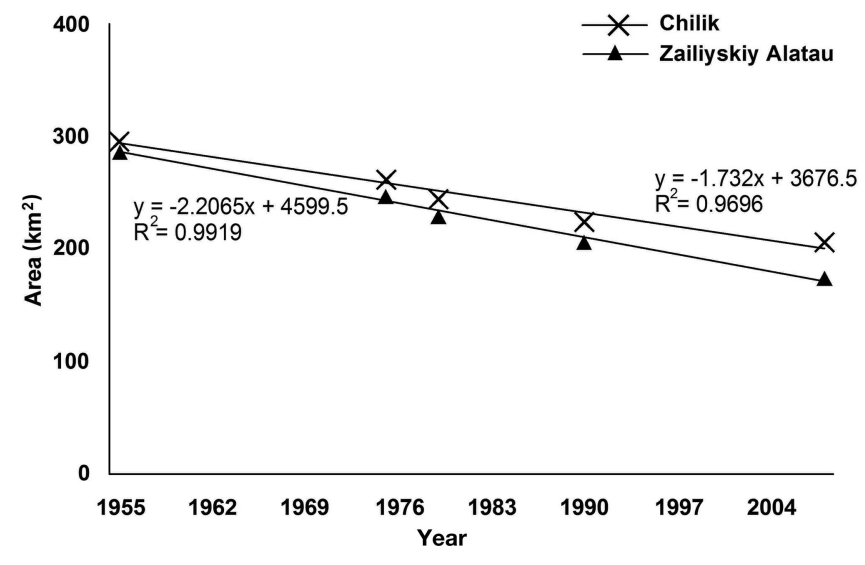

Fig. 6. Changes of glacierized area of Zailiyskiy-Kungei glacial system.

For comparison, we single out three glacial systems within the Balkhash-Alakol basin: the northern Ili system, which consists of glaciers on the northern slope of the Zailiyskiy Alatau; the Jungar glacial system, which includes glaciers in Kazakhstan's part of Jungar Alatau; and the upper Ili glacier system, which includes glaciers in the Chinese part of the Ili river basin.

\section{Changes in glacierization of the Jungar glacial system}

For Kazakhstan's part of Jungar Alatau, the unified glacier inventories have data for 1956, 1972, 1990, 2000 and 2011. We use the concept of stability of proportion of glacier area of a particular basin relative to the total glacier area of the corresponding glacial system to calculate the glacier area in the Jungar glacial system for 1979 and 2008, combining the Jungar and northern Ili glacial systems into a single system. Relevant area data are given in Table 5. Clearly, the

Table 4. Changes of glacierized area in Zailiyskiy-Kungei glacial system within Balkhash-Alakol basin using data from unified glacier inventories

\begin{tabular}{|c|c|c|c|c|c|c|c|c|c|c|}
\hline \multirow[t]{3}{*}{ District (basin) } & \multicolumn{5}{|c|}{ Glaciation area } & \multicolumn{5}{|c|}{ Average annual rate of reduction } \\
\hline & $1955 / 56$ & 1975 & 1979 & 1990 & 2008 & $1955 / 56-75$ & $1975-79$ & 1979-90 & 1990-2008 & 1955/56-2008 \\
\hline & $\mathrm{km}^{2}$ & $\mathrm{~km}^{2}$ & $\mathrm{~km}^{2}$ & $\mathrm{~km}^{2}$ & $\mathrm{~km}^{2}$ & $\% a^{-1}$ & $\% a^{-1}$ & $\% a^{-1}$ & $\% a^{-1}$ & $\% a^{-1}$ \\
\hline Zailiyskiy Alatau & 287.3 & 245.3 & 228.2 & 204.7 & 172.0 & -0.73 & -1.74 & -0.94 & -0.89 & -0.76 \\
\hline Chilik & 293.5 & 259.9 & 243.3 & 222.6 & 204.5 & -0.57 & -1.60 & -0.77 & -0.45 & -0.57 \\
\hline Total & 580.8 & 505.2 & 471.5 & 427.3 & 376.5 & -0.65 & -1.67 & -0.85 & -0.67 & -0.66 \\
\hline
\end{tabular}

Table 5. Calculated share of glacier area in northern Ili and Jungar glacial systems for the years of synchronous glacier cataloguing

\begin{tabular}{|c|c|c|c|c|c|c|c|}
\hline \multirow[t]{3}{*}{ Glacial system } & \multicolumn{6}{|c|}{ Area of glaciation for the year } & \multirow{3}{*}{$\begin{array}{c}\text { Average for } 3 \\
\text { years } \\
\text { \% }\end{array}$} \\
\hline & \multicolumn{2}{|c|}{$1955 / 56^{*}$} & \multicolumn{2}{|c|}{$1972 / 75^{+}$} & \multicolumn{2}{|c|}{1990} & \\
\hline & $\mathrm{km}^{2}$ & $\%$ & $\mathrm{~km}^{2}$ & $\%$ & $\mathrm{~km}^{2}$ & $\%$ & \\
\hline Northern Ili & 287.3 & 26.09 & 245.3 & 25.97 & 204.7 & 25.06 & 25.7 \\
\hline Jungar & 813.9 & 73.91 & 699.2 & 74.03 & 612.0 & 74.99 & 74.3 \\
\hline Total & 1101.2 & 100 & 944.5 & 100 & 816.7 & 100 & 100 \\
\hline
\end{tabular}

*1955 for northern Ili; 1956 for Jungar. ${ }^{\dagger} 1972$ for Jungar; 1975 for northern Ili. 
Table 6. Glacierized area of Jungar glacial system 1956-2011

\begin{tabular}{|c|c|c|c|c|c|c|}
\hline \multirow[t]{2}{*}{ Year } & \multirow[t]{2}{*}{ Unit } & \multicolumn{4}{|c|}{ Glacial districts in Kazakhstan's Jungar Alatau } & \multirow[t]{2}{*}{ Total } \\
\hline & & South & West & North & East & \\
\hline \multirow[t]{2}{*}{1956} & $\mathrm{~km}^{2}$ & 228.4 & 202.5 & 294.6 & 88.4 & 813.9 \\
\hline & $\%$ of total & 28.06 & 24.88 & 36.20 & 10.86 & 100 \\
\hline \multirow[t]{2}{*}{1972} & $\mathrm{~km}^{2}$ & 194.1 & 176.0 & 245.3 & 83.8 & 699.2 \\
\hline & $\%$ of total & 27.76 & 25.17 & 35.09 & 11.98 & 100 \\
\hline \multirow[t]{2}{*}{1990} & $\mathrm{~km}^{2}$ & 158.61 & 159.27 & 222.12 & 71.96 & 611.96 \\
\hline & $\%$ of total & 25.92 & 26.03 & 36.29 & 11.76 & 100 \\
\hline \multirow[t]{2}{*}{2000} & $\mathrm{~km}^{2}$ & 135.75 & 131.92 & 200.69 & 59.65 & 528.01 \\
\hline & $\%$ of total & 25.70 & 25.0 & 38.0 & 11.3 & 100 \\
\hline \multirow[t]{2}{*}{2011} & $\mathrm{~km}^{2}$ & 120.12 & 113.15 & 181.45 & 50.45 & 465.17 \\
\hline & $\%$ of total & 25.82 & 24.32 & 39.01 & 10.85 & 100 \\
\hline \multirow[t]{2}{*}{ Average } & $\mathrm{km}^{2}$ & 167.4 & 156.57 & 228.83 & 70.85 & 623.65 \\
\hline & $\%$ of total & 26.84 & 25.11 & 36.69 & 11.36 & 100 \\
\hline
\end{tabular}

*Average rate of reduction of glacierized area over 55 years (1956-2011).

proportion of glacier area of each glacial system relative to the total glacier area of the northern slope of the Zailiyskiy Alatau and Kazakhstan's part of Jungar Alatau is stable in time. Using the 3 year average values of fraction of glacier area of each glacial subsystem in the total area, it is possible to calculate glacier area of the Jungar glacial system for the inventory years 1979 and 2008 for the northern slope of the Zailiyskiy Alatau. According to these results, the glacierized area of the combined glacial system (northern Ili plus Jungar within Kazakhstan) for 2008 was $669.36 \mathrm{~km}^{2}$. The fraction of Jungar glacial system relative to the total area, on average, for the three years of synchronous glacier cataloguing was $74.31 \%$. Therefore, the area of the Jungar glacial system within Kazakhstan for 2008 can be estimated as $497.4 \mathrm{~km}^{2}$. Similarly, the calculated glacierized area of the Jungar glacial system for 1979 is $662.8 \mathrm{~km}^{2}$.

Next, we determine the glacier area in each of four districts of Kazakhstan's Jungar region relative to the total area of the Jungar glacial system on the basis of the glacier catalogues for 1956, 1972, 1990, 2000 and 2011 (Table 6).

According to the data given in Table 5, on average during the whole period studied, the highest rate of glacier shrinkage occurs on the southern flank of the Jungar Alatau, and the lowest rate in the northern and eastern districts. The glacier area of the whole Jungar system is reduced at an average rate of about $0.8 \% \mathrm{a}^{-1}$, which is similar to the average rate of reduction of glacier area in the Zailiyskiy-Kungei glacial system (Severskiy and others, 2006, 2012a,b), as well as glacierization of other outer ridges of the mountain systems in central Asia (Batyrov and Yakovlev, 2004; Aizen and other, 2006; Bolch, 2007, 2015; Kotlyakov and others, 2012; Sorg and others. 2012; Usubaliev and others, 2012; UngerShayesteh and others, 2013; Vilesov and others, 2014).

The fraction of glacier area of each district of Kazakhstan's Jungar Alatau is also stable in time (Table 6). Using 4 year averages of proportion of total glacier area of each district relative to the total area of Jungar glacial system and taking into account its share of the total glacier area of Jungar and Zailiyskiy-Kungei glacial systems (Table 5), we determined the glacier area of each district of Kazakhstan's Jungaria for 1979 and 2008 (Table 7; Fig. 7).

Clearly, changes in glacierization of the group of basins (regions) in Kazakhstan's part of the Jungar Alatau during the whole period of study occurred linearly. As reported by Severskiy and others (2006, 2012b), the highest rate of glacier mass loss is typically found in the basins of the southern Jungar Alatau, and the lowest rate is for the orographically closed basins.

Table 7. Changes in area of debris-free parts of glaciers in Kazakhstan's part of Jungar Alatau

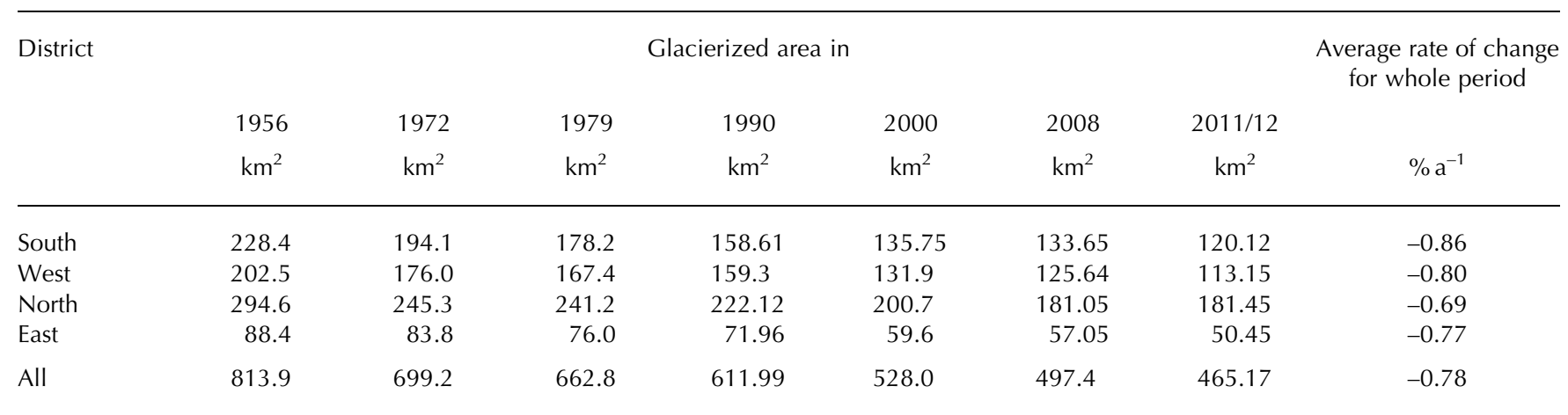

Notes: Inventories of glaciers in southern and western districts are based on satellite images in 2011, and in the northern and eastern districts on satellite images in 2012. Average rates of reduction of glacier area over 55 years in the first case, and over 56 years in the second case, are given in the rightmost column. The area of glaciers in the southern district of Kazakhstan's Jungaria for all years is given, and includes the area of glaciers in the part of the Khorgos river basin that was transferred to China in the 1990s by interstate agreement. 


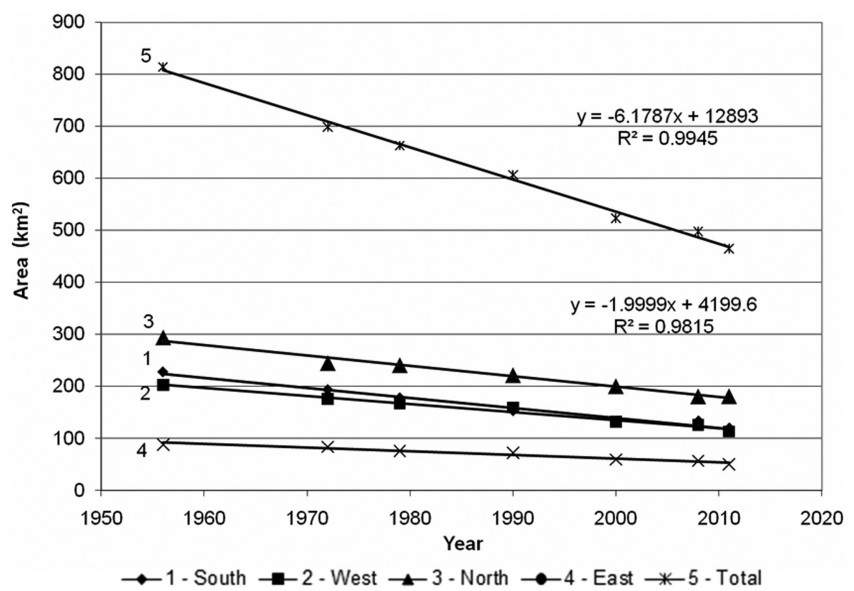

Fig. 7. Changes in the area of debris-free parts of glaciers in Kazakhstan's part of Jungaria. River basins: 1. Khorgos, Usek; 2. Karatal; 3. Biyen, Aksu, Lepsy; 4. Tentek, Rgaity; 5. all basins of Kazakhstan's part of Jungar Alatau.

\section{Changes in glacierization of the upper Ili glacial system}

It is more difficult to evaluate changes in the upper Ili glacial system, which combines glaciers from the Chinese part of the Ili river basin, because only two catalogues of glaciers are known for this territory. The first was prepared on the basis of aerial photography from 1962/63 using the topographic base of scale 1:100000 (Ding, 1986; Shi, 2008). The other is the second Chinese glacier inventory, completed on Landsat TM/ETM+ images from 2006-10 (Guo and others, 2015) and a study of changes of glaciers in Keksu river basin during 1963-2004 (Gao and others, 2011).

In addition to these catalogues, using Landsat 7 ETM+ satellite images, we have created a complete glacier catalogue of the Chinese part of the Ili river basin as of 2011, and catalogues of glaciers of the Khorgos river basin as of 2000, and Kash river basin as of 2008. Furthermore, on the basis of the data on glacier area in the Khorgos and Kash river basins and the share of glacier area of each particular basin relative to the total area of glacier ice in the Chinese part of the Ili river basin, we calculated the glacierized area of the whole upper Ili glacial system as of 2000 and 2008. As a result, we obtained values for the glacierized area of the Chinese part of the Ili river basin as of 1963, 2000, 2008 and 2011.

The glaciers, whose numbers could not be defined from the first catalogue, were assigned as 'unaccounted' for the earlier period; 294 such glaciers were found in the Chinese part of the Ili river basin, with a total area of $25.55 \mathrm{~km}^{2}$ and an estimated volume of $0.43 \mathrm{~km}^{3}$.

During the period since the first inventory of the Chinese part of the Ili river basin, 418 glaciers disappeared. Their total area was $65.46 \mathrm{~km}^{2}$ and their volume was $1.41 \mathrm{~km}^{3}$. The highest losses of glacier area are for the Kunges and Khorgos river basins. That could be explained by relatively low elevations of the ridges as well as by the southern aspect of most of the glacier ice. Owing to the disintegration of large glaciers into fragments, the total number of glaciers in the Chinese part of the Ili river basin increased 1.5-fold during the period 1963-2011. The area of their debris-free parts decreased by $29 \%$, and the ice volume by $45 \%$.

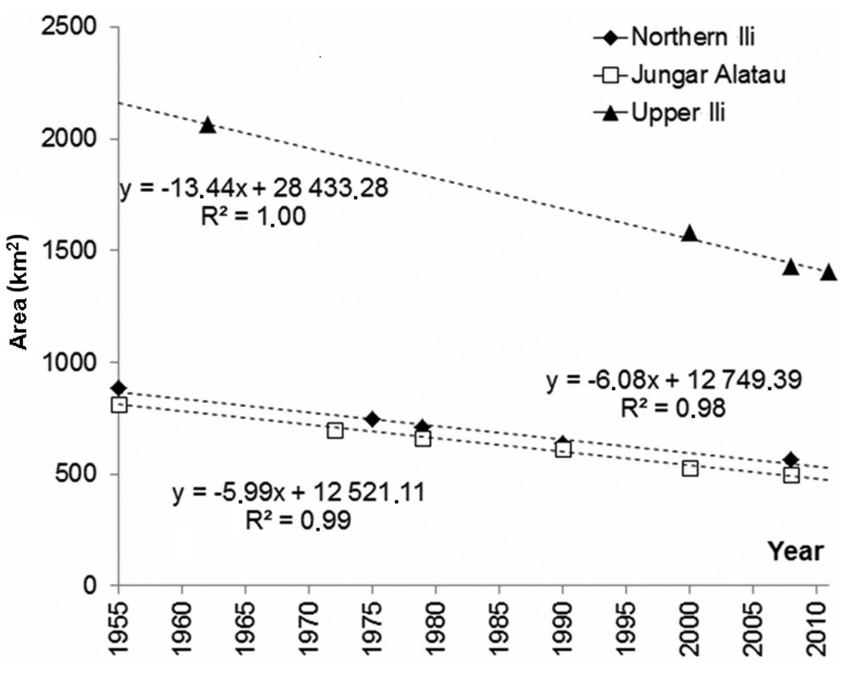

Fig. 8. Changes in debris-free glacier area in the Balkhash-Alakol basin. Glacial systems: 1. northern Ili, 2. Jungar, 3. upper Ili.

\section{Comparisons of glacierization changes in the three glacier systems}

We compared the data on the dynamics of glacierization of the three main glacial systems within the Balkhash-Alakol basin (northern Ili, Jungar and upper Ili) for similar periods, and the final results of evaluation of changes in glacierization are given in Table 8. Changes in area of the debris-free parts of the glaciers in these three glacial systems are compared in Figure 8. The rates of reduction of the glacier area in the northern Ili and Jungar glacial systems during the period from $1955 / 56$ to 2008 are -0.76 and $-0.75 \% \mathrm{a}^{-1}$, respectively.

The rate of reduction of glacier area in the upper Ili glacial system from 1963 to 2008 , on average, is $-0.68 \% \mathrm{a}^{-1}$. On the basis of the glacier area of all three glacial systems in the Balkhash-Alakol basin for 2000 and 2008, we determined the fraction of glacierized area of each of them compared to the total area. On average, for the two years it amounted to $8.08 \%$ for the northern Ili glacier system, $23.38 \%$ for the Jungar system and $68.54 \%$ for the upper Ili glacial system.

On the basis of these results and calculated areas of the northern $\mathrm{Ili}$ and Jungar glacial systems, and taking into account the stability of correlations of glacierized area in the particular basins (or groups of basins) relative to total glacier area of the respective total glacial system, we calculated the glacierized area of the Chinese part of the lli river basin as of 1956 to be $2386.3 \mathrm{~km}^{2}$. We also estimate the average rate of glacier mass change of the upper Ili glacial system from 1956 to 2008 to be $-0.73 \% \mathrm{a}^{-1}$, which is comparable with the rates of reduction of glacierized area in the northern $\mathrm{Ili}$ and Jungar glacial systems during the same period.

The results obtained lead us to conclude that, in spite of significant inter-basin differences, glacierization of the three glacial systems in the Ili river basin within Kazakhstan as well as on Chinese territory is changing uniformly. Differences in the rates of glacier shrinkage are small. On the southern flanks of the ridges, the rates of mass loss are much higher during the comparable periods than they are on the northern flanks. Minimum rates of glacier mass loss are found in orographically closed basins on the eastern periphery of the mountainous countries. 
Table 8. Changes in glacierized area $\left(\mathrm{km}^{2}\right)$ of glacial systems $(S)$ in Balkhash-Alakol basin

\begin{tabular}{|c|c|c|c|c|c|c|c|}
\hline \multirow[t]{2}{*}{ River basin (district) } & \multicolumn{7}{|c|}{ Area of debris-free glacier parts in } \\
\hline & $1955 / 56^{*}$ & $1972 / 75^{+}$ & 1979 & 1990 & 2000 & 2008 & 2011 \\
\hline \multicolumn{8}{|l|}{ Northern Ili glacial system } \\
\hline Northern slope of Zailiyskiy Alatau & 287.3 & 245.3 & 228.4 & 204.7 & 182.6 & 172.0 & \\
\hline \multicolumn{8}{|l|}{ Jungar glacial system } \\
\hline Khorgos, Usek (southern) & 228.4 & 194.1 & 178.2 & 158.6 & 135.8 & 133.6 & 120.1 \\
\hline Karatal (western) & 202.6 & 176.0 & 167.4 & 159.3 & 131.9 & 125.6 & 113.2 \\
\hline Biyen, Aksu, Lepsy (northern) & 294.6 & 245.3 & 241.2 & 222.1 & 200.7 & 181.0 & 181.4 \\
\hline Tentek, Rgaity (eastern) & 88.4 & 83.8 & 76.0 & 72.0 & 59.6 & 57.0 & 50.4 \\
\hline Total & 814.0 & 699.2 & 662.8 & 612.0 & 528.0 & 497.4 & 465.2 \\
\hline Upper Ili glacial system & & $1962 / 63$ & & 2000 & 2008 & & 2011 \\
\hline Khorgos & & 62.3 & & 41.7 & 32.2 & & 31.6 \\
\hline Kash & & 423.7 & & 336.9 & 316.8 & & 311.5 \\
\hline Kunges & & 97.4 & & 69.0 & 57.5 & & 56.6 \\
\hline Keksu & & 439.3 & & 342.0 & 314.3 & & 309.1 \\
\hline Tekes & & 1039.8 & & 789.9 & 709.3 & & 697.4 \\
\hline Total & & 2062.5 & & 1579.5 & 1430.1 & & 1406.2 \\
\hline
\end{tabular}

*1955 for northern Ili; 1956 for Jungar. ${ }^{\dagger} 1972$ for Jungar; 1975 for northern Ili.

\section{CONCLUSION}

The results of comparative analysis of the data from the series of unified inventories of glaciers of the ZailiyskiyKungei glacial system for 1955, 1975, 1979, 1990 and 2008, for the Jungar glacial system for 1956, 1972, 1990, 2000 and 2011, and for the upper Ili glacial system for 1963 and 2011 leave no doubt that the fraction of glacier area of particular basins relative to the total area of glacierization of the respective glacial system is stable in time. This finding allows for operational monitoring of the state and dynamics of glacial systems through the measurement of glacier area in selected basins. By varying the structure and glacier area of the glacial systems, we can make the glacier areas of different particular glacial subsystems more comparable and we can shed light on the reasons for inter-basin differences of glacier response to climate change. Although there are significant inter-basin differences, the glacierization of the studied systems is characterized by common trends and similar rates of reduction in glacier area and volume.

The glacial systems of the Balkhash-Alakol basin have changed linearly over the whole study period, with similar shrinkage rates. Glacier degradation is generally linear for the whole period studied. Rates of glacier reduction in the Balkhash-Alakol basin follow changes in accumulation (winter mass balance) and summer temperature. Rates of degradation of glaciers increased markedly at the beginning of the study period and, after reaching a maximum in the mid-1970s, decreased thereafter.

Judging by the dynamics of components of the mass balance of Tuyuksu glacier, the period of most intensive degradation ended at the beginning of the 1980s and, starting from the mid-1990s, the annual mass balance became less negative. The glacier has therefore seen a slight improvement in conditions for its continued existence.

\section{ACKNOWLEDGEMENTS}

This study was funded by a grant from the Ministry of Education and Science of the Republic of Kazakhstan (under treaty No. 260), also supported by the CHARIS research project and the Newton-Al-Farabi Partnership Programme, grant No. 172722855 .

\section{REFERENCES}

Aizen V, Aizen E, Melack J and Dozier J (1997) Climatic and hydrologic changes in the Tien Shan, Central Asia. J. Climate, 10, 1393-1404 (doi: 10.1175/1520-0442(1997)010<1393: CAHCIT>2.0.CO;2)

Aizen V, Kuzmichenok V, Surazako A and Aizen E (2006) Assessment of glacial area and volume change in Tien Shan (Central Asia) during the last 140 years. Ann. Glaciol., 43, 202-213

Aizen V, Kuzmichenok V, Surazakov A and Aizen E (2007) Glacier changes in the Tien Shan as determined from topographic and remotely sensed data. Global Planet. Change, 56, 328-340

Batyrov R and Yakovlev Đ (2004) Monitoring gornih lednikov nekotorih raionov Gissro-Alaya s ispolzovaniem kosmicheskih snimkov ASTER TERRA [Monitoring of mountain glaciers in some areas of Gissar-Alai using satellite imagery ASTER TERRA]. Glaciol. gornih raionov. Trudi NIGMI [Glaciology in mountain areas: NIGMI works], 3(248), 22-27

Bolch T (2006) GIS- und fernerkundungsgestützte Analyse und Visualisierung von Klima- und Gletscheränderungen im nördlichen Tien Shan (Kasachstan/Kyrgyzstan) mit einem Vergleich zur Bernina-Gruppe/Alpen. (Dissertation, Friedrich-AlexanderUniversität Erlangen-Nürnberg)

Bolch T (2007) Climate change and glacier retreat in northern Tien Shan (Kazakhstan/Kyrgyzstan) using remote sensing data. Global Planet. Change, 56, 1-12

Bolch T (2015) Glacier area and mass changes since 1964 in Ala Archa Valley, Kyrgyz Ala-Too, northern Tien Shan. Led i Sneg [Snow and Ice], 1(129), 28-39

Bolch T and Marchenko SS (2009) Significance of glaciers, rockglaciers and ice rich permafrost in the Northern Tien Shan 
as water towers under climate change conditions. In Braun L, Hagg W, Severskiy I and Young G eds Assessment of snow, glacier and water resources in Asia, vol. 8. International Hydrological Programme - Hydrology and Water Resources Programme, Koblenz, 132-144

Bolch T, Menounos B and Wheate RD (2010) Landsat-based inventory of glaciers in western Canada, 1985-2005. Remote Sens. Environ., 114, 127-137

Cao MS (1998) Detection of abrupt changes in glacier mass balance in the Tien Shan mountains. J. Glaciol., 44, 352-358

Cherkasov P (1969) Katalog lednikov SSSR. Vol. 13. Centralnii i Ujnii Kazakhstan, Issue 2. Bassein ozera Balkhash, part 7 [Glaciers inventory of the USSR. Vol. 13. Central and Southern Kazakhstan. Issue 2 Balkhash lake Basin, part 7]. Hydrometeoizdat, Leningrad, 82

Cherkasov P (1970) Katalog lednikov SSSR. Vol. 13. Centralnii i Ujnii Kazakhstan, Issue 2. Bassein ozera Balkhash, part 6 [Glaciers inventory of the USSR. Vol. 13. Central and Southern Kazakhstan. Issue 2 Balkhash lake Basin, part 6]. Hydrometeoizdat, Leningrad, 84

Cherkasov P (1975) Katalog lednikov SSSR. Vol. 13. Centralnii $i$ Ujnii Kazakhstan, Issue 2. Bassein ozera Balkhash, part 4 [Glaciers inventory of the USSR. Vol. 13. Central and Southern Kazakhstan. Issue 2 Balkhash lake Basin, part 4]. Hydrometeoizdat, Leningrad, 83

Cherkasov P (1980) Katalog lednikov SSSR. Vol. 13. Centralnii i Ujnii Kazakhstan, Issue 2. Bassein ozera Balkhash, part 5 [Glaciers inventory of the USSR. Vol. 13. Central and Southern Kazakhstan. Issue 2 Balkhash lake Basin, part 5]. Hydrometeoizdat, Leningrad, 82

Cherkasov P (2002) Sovremennoe sostoyanie lednikov IliBalkhashskogo regiona [Modern state of glaciers of the Ili-Balkhash Region]. In Kudekov TK ed. Sovremennoe ecologicheskoe sostoyanie basseina ozera Balkhash [Modern ecological state of the Balkhash Lake Basin]. Kaganat, Almaty, 141-198

Cherkasov P and Nikitin SA (1989) K metodike rascheta ob'ema gornih lednikov po dannim nazemnoi i vozdushnoi radiolokacionnoi s'emki (na primere Dzhungarskogo Alatau) [To a design procedure of volume of glaciers according to ground and air radar-tracking shooting (on an example Dzungarian Alatau)]. Ledniki, snezhnii pokrov i lavini v gorah Kazakhstana [Glaciers, snow cover and avalanches in mountains of Kazakhstan]. Nauka, Alma-Ata, 18-37

Cogley JG (2016) Glacier shrinkage across High Mountain Asia. Ann. Glaciol. 57(71) 41-49 (doi: 10.3189/2016AoG71A040) (see paper in this issue)

Desinov L and Konovalov V (2007) Distancionnyi monitoring mnogoletnego rezhima oledeneniya Pamira [Distant monitoring of the long-term regime of glaciers in the Pamir]. Mater. Glaciol. Issled. [Data Glaciol. Stud.], 103, 129-133

Ding L, Xie W, Liu C, Wang C and Wang Z eds (1986) Glacier inventory of China III. Tienshan mountains (Ili River Drainage Basin). Science Press, Beijing [in Chinese]

Driedger C and Kennard P (1986) Glacier volume estimation on Cascade volcanoes: an analysis and comparison with other methods. Ann. Glaciol., 8, 59-64

Dyurgerov M (2010) Reanalysis of glacier changes: from the IGY to the IPY, 1960-2008. Data Glaciol. Stud., 108, 116

Dyurgerov M and Meier M (2005) Glaciers and the changing earth system: a 2004 snapshot. (INSTAAR Occasional Paper 58) Institute of Arctic and Alpine Research, University of Colorado, Boulder, $\mathrm{CO}$

Eder KI, Geiss N, Rentsch H, Kokarev E and Uvarov V (2005) Surveying and mapping of the Tuyuksu Glacier Region, Kazakhstan, 1:10000. In World Glacier Monitoring Service, Fluctuations of glaciers 1995-2000 (Vol. VIII), ed. Haeberli W, Noetzli J, Zemp $M$, Baumann S and Frauenfelder R. ICSU (FAGS)/IUGG (IACS)/UNEP/UNESCO/WMO, World Glacier Monitorig Service, Zürich, 72-73
Farinotti D and 7 others (2015) Substantial glacier mass loss in the Tien Shan over the past 50 years. Nature Geosci., 8 , 716-722

Fateev V and Cheban V (1969) Katalog lednikov SSSR Tom.14, vyp. 2, tcast 4. Basseyny pravykh pritokov rekir Chu nozhe Baamskogo ustchelia [Catalog of glaciers of the SSSR Vol. 14, issue 2, part 4. Basins of the right tributaries of the Chu river laver Boam Canyon]. Hydrometeoizdat, Leningrad, 60

Gao WY, Li ZQ, Li KM and Zhang M (2011) Glacier variation in the Kukesu River basin during 1963-2004 based on remote sensing data and GIS techniques. Arid Land Geogr., 34(2), 252-261 [in Chinese with English summary]

Gletschergebiet Tujuksu, Sailiski Alatau (1961) M 1:10000. Institut für Kartographie T.H. Dresden-VEB Hermann Haack, Dresden

Guo W and 10 others (2015). The second Chinese glacier inventory: data, methods and results. J. Glaciol., 61(226), 357-372 (doi: 10.3189/2015JoG14J209)

Kaldybayev A, Chen Y and Vilesov E (2016) Glacier change in Karatal river basin, Zhetysu (Dzhungar) Alatau, Kazakhstan. Ann. Glaciol., 57(71), 11-19 (doi: 10.3189/2016AoG71A005) (see paper in this issue)

Kokarev A and Shesterova I (2011) Izmenenie lednikovih system severnogo sklona Zailiiskogo Alatau vo vtoroi polovine XX i nachale XXI vekov [Change of the glacier systems on the northern slope of Zailiyskiy Alatau for the second half of XX and the beginning of XXI centuries]. Led $i$ Sneg [Ice and Snow], 4(116), 39-46

Kotlyakov V (2004) Izbrannie sochineniya. Kniga 2. Snezhnii pokrov i ledniki Zemli [Selected works. Book 2. Snow cover and glaciers of the Earth]. Nauka, Moscow

Kotlyakov V ed. (2006) Oledenenie Sevenoi i Centralnoi Eurasii v sovremennuyu epohu [Glaciation in North and Central Eurasia at present time]. Nauka, Moscow

Kotlyakov V and Komarova A (2007) Geography: concepts and terms: dictionary in five languages. Nauka, Moscow

Kotlyakov V and Severskiy I (2009) Glaciers of central Asia: current situation, changes and possible impact on water resources. In Braun L, Hagg W, Severskiy I and Young G eds Assessment of snow, glacier and water resources in Asia, vol. 8. International Hydrological Programme-Hydrology and Water Resources Programme, Koblenz, 151-159

Kotlyakov V, Xie Zi-chu, Shishong M, Wamg X, Khromova T and Nosenko G (2012) Changing of the Altai glacier system since the mid-twentieth century and its response to the climate warming in future. Ice Snow, 3(119), 17-24

Kutuzov S (2012) Izmenenie ploshchadi i obema lednikov khr. Terskej Ala-Too vo vtoroj polovine XXV [Glacier surface area and volume changes in the Terskey Ala-Too, Tien-Shan in the second half of the 20th century]. Led i Sneg [Ice and Snow], 117, 5-14.

Kutuzov S and Shahgedanova M (2009) Glacier retreat and climatic variability in the eastern Terskey-Alatoo, inner Tien Shan between the middle of the 19th century and beginning of the 21st century. Global Planet. Change, 69, 59-70

Li B, Zhu AX, Zhang Y, Pei T, Qin C and Zhou C (2007) Glacier change over the past four decades in the middle Chinese Tien Shan. J. Glaciol., 52(178), 425-432 (doi: 10.3189/ 172756506781828557)

Liu S and 7 others (2006) Glacier retreat as a result of climate warming and increased precipitation in the Tarim river basin, northwest China. Ann. Glaciol., 43, 91-96 (doi: 10.3189/ 172756406781812168)

Macheret Yu.Ya., Cherkasov P and Bobrova L (1988) Tolschina i ob'em lednikov Dzjungarskogo Alatau po dannym aeroradiatsionnogo zondirovaniya [Thickness and volume of glaciers of the Jungar Alatau on the data of radiecho soundings]. Mater. Glaciol. Issled. [Data Glaciol. Stud.], 62, 59-71

Makarevich K and 7 others (1969) Oledenenie Zailiiskogo Alatau [Glaciation of Zailiyskiy Alatau]. Nauka, Moscow 
Makarevich K, Vilesov E, Golovkova R, Denisova T and Shabanov P (1984) Lednik Tuyuksu [Tuyuksu glaciers]. Gidrometeoizdat, Leningrad

Narama C, Shimamura Y, Nakayama D and Abdrakhmatov K (2006) Recent changes of glacier coverage in the western Terskey-Alatoo range, Kyrgyz Republic, using Corona and Landsat. Ann. Glaciol., 43, 223-229 (doi: 10.3189/172756406781812195)

Narama C, Severskiy I and Yegorov A (2009) Current state of glacier changes, glacial lakes, and outburst floods in the lle Ala-Tau and Kungoy Ala-Too ranges, northern Tien Shan mountains. Ann. Hokkaido Geogr., 84, 22-32

Narama C, Kääb A, Duishonakunov M and Abdrakhmatov K (2010) Spatial variability of recent glacier area changes in the Tien Shan Mountains, Central Asia, using Corona ( 1970), Landsat ( 2000), and ALOS ( 2007) satellite data. Global Planet. Change, 71, 42-54

Niederer P, Bilenko V, Ershova N, Hurni $\mathrm{H}$, Yerokhin $\mathrm{S}$ and Maselli D (2007) Tracing glacier wastage in the Northern Tien Shan (Kyrgyzstan/Central Asia) over the last 40 years. Climate Change, 86, 227-234 (doi: 10.1007/s10584-007-9288-6)

Nikitin S (2009) Zakonomernosti raspredeleniya lednikovih resursov v Russkom Altae, ocenka ih resursov i dinamiki [Pattern of distribution of ice in the Russian Altai glaciers, evaluation of its resources and dynamics]. Mater. Glaciol. Issled. [Data Glaciol. Stud.], 107, 87-96

Nuimura T and 12 others (2014). The GAMDAM glacier inventory: a quality-controlled inventory of Asian glaciers. Cryosphere Discuss., 8, 2799-2829 (doi: 10.5194/tcd-8-2799-2014)

Osmonov A, Bolch T, Xi C, Wei J and Kurban A (2013) Glacier characteristics and changes in the Sary-Jaz River Basin (Central Tien Shan) 1990-2010. Remote Sens. Lett., 4, 725-734.

Paul F and 9 others (2009) Recommendations for the compilation of glacier inventory data from digital sources. Ann. Glaciol., 50(53), 119-126 (doi: 10.3189/172756409787769528)

Paul F and 19 others (2013). On the accuracy of glacier outlines derived from remote-sensing data. Ann. Glaciol., 54(63), 171-182 (doi: 10.3189/2013AoG63A296)

Pfeffer W and 18 others (2014). The Randolph Glacier Inventory: a globally complete inventory of glaciers. J. Glaciol., 60(221), 537-552 (doi: 10.3189/2014JoG13J176)

Pieczonka T and Bolch T (2015) Region-wide glacier mass budgets and area changes for the Central Tien Shan between $\sim 1975$ and 1999 using Hexagon KH-9 imagery. Global Planet. Change, 128, $1-13$

Severskiy I (2009) Current and projected changes of glaciation in Central Asia and their probable impact on water resources. In Braun L, Hagg W, Severskiy I and Young G eds Assessment of snow, glacier and water resources of Asia, vol. 8. International Hydrological Programme-Hydrology and Water Resources Programme, Koblenz, 99-111

Severskiy I (2011) K probleme monitoringa izmeneniya oledeneniya tselostnikh glyatsialnikh system [On the problem of monitoring of changes in glaciation of holistic glacial systems]. Vop. Geog. Geoecol. [Iss. Geog. Geoecol.], 2, 12-18

Severskiy IV, Kokarev AL, Severskiy SI, Tokmagambetov TG, Shesterova IN and Shagarova LI (2006) Contemporary and prognostic changes of glaciation in Balkhash Lake basin. Kaganat, Almaty

Severskiy I, Kokarev A and Pimankina N (2012a) Snezhnie I ledovie resursi Kazakhstana. Vodnie resursi Kazakhstana: Otsenka, Prognoz, Upravlenie [Snow and ice resources of Kazakhstan. Water Resources of Kazakhstan: assessment, prediction, control: In vol. VI]. Kaganat, Almaty, 246

Severskiy I and 6 others (2012b) Lednikovie systemy BalkhashAlakolskogo Basseina: sostoyanie, sovremennie izmeneniya [Glacier systems of the Balkhash-Alakol basin: state, contemporary changes]. Voprosy. Geogr. Geoecol. [Issled. Geogr. Geoecol.], 2, 31-40
Shangguan D and 9 others (2006) Monitoring the glacier changes in the Muztag Ata and Konggur mountains, east Pamirs, based on Chinese Glacier Inventory and recent satellite imagery. Ann. Glaciol., 43, 79-85 (doi: 10.3189/172756406781812393)

Shchetinnikov SA (1998) Morphologiya i regime lednikov PamiroAlaya [The morphology and regime of Pamir-Alai glaciers]. Central Asia Hydro-Meteorological Institute, Tashkent

Shi Y (2008) Concise Glacier Inventory of China. Shanghai Popular Science Press, Lanzhou

Sorg A, Bolch T, Stoffel M, Solomina O and Beniston M (2012) Climate change impacts on glaciers and runoff in Tien Shan (Central Asia). Nature Climate Change, 2(10), 725-731

Unger-Shayesteh $\mathrm{K}$ and 6 others (2013) What do we know about past changes in the water cycle of Central Asian headwaters? A review. Global Planet. Change, 110, 4-25

Usubaliev R, Dudashvily A, Elemanov O (2012) Oledenenie cevernykh sklonov Turkestanskogo b Alayskogo khrebtov i ego covremennaya dinamika [Glacierization of the northern slopes of the Turkestan and Alai ridges and their contemporary dynamics]. Led I Sneg [Snow and Ice], 1(117), 24-28

Vilesov E (1968) Katalog lednikov SSSR. Vol. 13. Centralnii i Ujnii Kazakhstan, Issue 2. Bassien ozera Balkhash, part 2 [Glaciers inventory of the USSR. Vol. 13. Central and Southern Kazakhstan. Issue 2 Balkhash lake Basin, part 2]. Hydrometeoizdat, Leningrad

Vilesov E (1969) Katalog lednikov SSSR. Vol. 13. Centralnii i Ujnii Kazakhstan, Issue 2. Bassien ozera Balkhash, part 3 [Glaciers inventory of the USSR. Vol. 13. Central and Southern Kazakhstan. Issue 2 Balkhash lake Basin, part 3]. Hydrometeoizdat, Leningrad

Vilesov E and Khonin R (1967) Katalog lednikov SSSR. Vol. 13. Centralnii i Ujnii Kazakhstan, Issue 2. Bassien ozera Balkhash, part 1 [Glaciers inventory of the USSR. Vol. 13. Central and Southern Kazakhstan. Issue 2 Balkhash lake Basin, part 1.] Hydrometeoizdat, Leningrad

Vilesov E and Morozova V (2003) Lednik Tuyuksu; resultati sravneniya s'emok 1958 i 1998 [Tuyuksu glacier: the results of the comparison of the surveys as of 1958 and 1998]. Gidrometeorol. ecol. [Hydrometeorol. Ecol.], 3, 82-90

Vilesov E and Uvarov V (2001) Evoluciya sovremennogo oledeneniya Zailiyskogo Alatau $\vee X X$ veke [The evolution of modern glaciation of Zailiyskiy Alatau in XX century]. PH KazNU, Almaty

Vilesov E, Morozova V and Severskiy I (2013) Oledenenie Dzhungarskogo (Zhetysu) Alatau: proshloe, nastoyashee, budushee [Glaciation of Jungar (Zhetysu) Alatau: past, present, future]. Volkova, Almaty

Vilesov E, Severskiy I and Morozova V (2014) Dinamika oledeneniya Kazakhstanskogo Altaya za 60 let [Dynamics of glaciation in the Kazakh part of Altai during 60 years]. Led $i$ Sneg [lce and Snow], 2(126), 14-21

Vinogradov ON and Krenke AN eds (1966) Rukovodstvo po sostavleniyu kataloga lednikov SSSR [Guide to the compilation of the Catalogue of Glaciers of the USSR]. Hydrometeoizdat, Leningrad

WGMS (2008) Global glacier changes: facts and figures, ed. Zemp M, Roer I, Kääb A, Hoelzle M, Paul F and Haeberli W. UNEP, World Glacier Monitoring Service, Zürich

WGMS (2013) Glacier mass balance bulletin No. 12 (2010-2011), ed. Zemp $M$ and 6 others. ICSU (WDS)/IUGG (IACS)/UNEP/ UNESCO/WMO, World Glacier Monitoring Service, Zürich (doi: 10.5904/wgms-fog-2013-11)

Yao T, Wang Y, Liu S, Pu J, Shen Y and Lu A (2009) Recent glacial retreat in the Chinese part of High Asia and its impact on water resources of Northwest China. In Braun L, Hagg W, Severskiy I and Young G eds Assessment of snow, glacier and water resources of Asia, vol. 8. International Hydrological Programme-Hydrology and Water Resources Programme, Koblenz, 26-35 